\title{
Implementation of Work-life Balance in Companies - The Case of Poland
}

\author{
Patrycja ZWIECH \\ University of Szczecin, Institute of Management, Faculty of Economics, \\ Finance and Management, Szczecin, Poland \\ E-mail: patrycja.zwiech@usz.edu.pl
}

Received date: 24 November 2020; Accepted date: 21 January 2021; Published date: 3 August 2021

Copyright (C) 2021. Patrycja ZWIECH. Distributed under Creative Commons Attribution 4.0International CC-BY 4.0

\begin{abstract}
Making it easier for employees to maintain work-life balance and to facilitate the combination of different social roles increases job satisfaction. WLB is usually analysed in the context of a conflict between various requirements relating to involvement in one's work and playing other important life roles. Questionnaire surveys were carried out to assess the implementation of work-life balance systems in enterprises and to identify what factors cause employees to be satisfied in the spheres of work and private life. The survey was conducted on 601 employees from the West Pomeranian Voivodship in Poland. Only selected questionnaire questions were used for the analysis carried out in this article, which was part of a larger study on human resources management in enterprises. The questionnaire covered both closed and open questions. Research shows that only half of respondents said that their companies have programmes in place to facilitate the linking of work and private life. Respondents also pointed to work-related factors that determine a happy, successful life. It turned out that factors dependent on work (such as satisfactory work, good working conditions) are an important condition for a successful life.
\end{abstract}

Keywords: Work-Life Balance, Human Capital, Company, Poland.

\section{Introduction}

Negative consequences of absence of a balance between a private life and a professional life contributed to the emergence in the USA in the 1970s of the concept of a "work-life balance" (Sadowska-Snarska, 2014, pp. 33-34). At first, definitions of a lack of balance tended to focus only on the interface between work and private life (Resch, 2003), and with time this lack of balance was defined in broader terms as a harmonious interface between different life domains (Frone, 2003). Currently WLB is defined as an ability to combine work with other life dimensions, i.e., a family life, social activity, one's own development, rest and personal interests so that work does not appropriate life outside of it and non-professional life is not limited by one's work situation (Borkowska, 2011, p. 18; Sadowska- 
Snarska, 2014, pp. 21-46). Robak and Słocińska (2014, pp. 114-116) suggest that WLB should be understood as a continuous process of balancing work with a nonprofessional life. In turn Clutterbuck (2005, p. 26) defines WLB as a subjectively perceived state in which an individual manages the potential conflict between these two spheres of their life in the context of time and energy devoted to them and the sense of self-fulfilment. The worklife balance may be also defined as efficiency of the relation between work and private life or as systemic solutions which enable professionally active people to maintain a balance between their jobs and a private life and help in combining various social roles so as to achieve satisfaction in both life spheres. To sum up, WLB is defined in various ways and different authors refer in their definitions to: the ability to combine, the efficiency of the relation, a process, a state or refer in their definitions to: systemic solutions implemented by organizations.

At the same time, we need to define what is meant when we talk about "balance". Greenhaus, Collins and Show (2003, pp. 510-531) mostly point to the time devoted to the main areas of functioning of professionally active people, i.e., work and family. Great involvement in one's work often contributes to devoting maximum time to it, often to the detriment of other significant values, which makes the entire life style adapt to the requirements of the job. In turn, Greenhaus, Collins and Show (2003) believe that WLB should refer to three different balances:

$$
\begin{aligned}
& \text { - time balance } \\
& \text { - involvement balance } \\
& \text { - satisfaction balance (equal } \\
& \text { satisfaction with work and } \\
& \text { family) }
\end{aligned}
$$

Kisil (2018) points out that we should consider an individual's resources of time, energy, thoughts and emotions which are difficult to divide into separate parts between work and private life as they are used in both these spheres.
It is also pointed out that the concept of balance may be inadequate and a different one should be suggested in its place - the concept of work and personal life integration or interaction (Warhurst, Eikhof, Haunschild, 2008). The term worklife balance implies that work and life are distinct spheres and that time should be split "equally" between work and private life. Rapoport, Bailyn, Fletcher et.al (2002) point out that people may have differing priorities in that regard, and that the aim is not always an even balance between the two. Apart from this, Campbell Clark (2000, p. 748) notes that not everyone wants to integrate the domains of work and family/personal life. On the contrary, some people balance their work and personal life by keeping the two strictly separate.

In this paper the author assumes that WLB does not mean an "equal" division of time, involvement and satisfaction between work and other activities, and similarly, the amount of time allocated to certain activities and their frequency does not constitute the importance of these activities to an individual. This results from subjectivism in the assessment of a relation between work and private life, which is a result i.e., of the individual's system of values, his family situation, job type, behavioural features, age, gender, health, social culture, socialisation and the company's organizational culture. WLB should, in turn, mean an optimal division for the individual.

The purpose of this paper is to present the concept of work-life balance in the theoretical approach and research results demonstrating implementation of system solutions which make it easier for professionally active people to maintain a balance between their jobs and private lives and facilitate combining various social roles to achieve satisfaction in both spheres of life in the companies of the West Pomeranian province in Poland.

\section{Literature Review}

WLB is usually analysed in the context of a conflict between various requirements relating to involvement in one's work and

Patrycja ZWIECH (2021), Journal of Human Resources Management Research, DOI: $10.5171 / 2021.811071$ 
playing other important life roles. There is a large body of literature examining the predictors and outcomes of work-family conflict based on the definition given by Greenhaus and Beutell (1985, p. 77). They defined WLB as "a form of interrole conflict in which the role pressures from the work and family domains are mutually incompatible in some respect". This definition stresses the bidirectional relationship. This conflict is understood on the one hand as work appropriating private life in a situation where non-professional life is carried out to the detriment of work (Borkowska, 2004, p. 54, Clutterbuck, 2005 , p. 26). On the other hand, this conflict may be also understood in a contrary way, when private life appropriates work life. Family can interfere with work and work can interfere with private life. Recently, work-family enrichment and work-life facilitation concepts have stressed positive interdependencies, noting that work can also benefit private life and vice versa (Greenhaus, Powell, 2006; Grzywacz, Marks, 2000).

In the context of the theory of conflict, a balance between a professional and private life is defined as a state in which an individual manages the potential conflict between various demands on their time and energy so that their desire for wellbeing and satisfaction is met (Campbell Clark, 2000, pp. 747-770). Thus, an individual perceives WLB as a satisfactory state with a possibly minimal parallel conflict of roles.

The consequences of distorting the balance between family and professional life may be approached both in a broad social perspective and in an individual perspective (Borkowska, 2003, p. 15). The effects of lack of work-life-balance include: burnout, diminished well-being, physical ailments, mental ailments, health issues, lack of satisfaction from work or life, stress, growing frustration, low self-esteem, family conflicts and problems with fulfilling family roles, divorce or addiction. The outcomes affecting an individual entail consequences to companies, such as diminished work effectiveness, fluctuation, disorganisation of work, increased backlog, missed deadlines, sickness-related absences, increased operational costs or deteriorated atmosphere at work. They also cause consequences to the state and society: they lead to declining birth rates, increase social inequalities, lead to family dysfunctions, cause a breakdown of social bonds, increase the health care system's burden with new patients suffering from heart issues, oncological diseases and neurological conditions or increase workrelated passivity.

Integration of company goals with employee goals is the basis of effective company operation. Thanks to this, all actions which facilitate reconciliation of private and professional life of staff contribute to a greater efficiency of the company. Activities for work-life balance are, therefore, a manifestation of investing in human capital and at the same time contribute to increasing the company's competitive leverage. Usually these activities concern five areas (Cascio, 2001, p. 180):

- assisting an employee in looking after their children (including also increased access to child care places and dependent persons' facilities),

- flexible working conditions,

- occasional days off at the request of an employee,

- information services in terms of e.g., health, law, culture,

- $\quad$ ensuring broadly understood help and assistance for employees in non-professional spheres.

But one can also add to them preventing professional qualifications from getting outdated while being absent from work due to family obligations and promotion of male employees' greater involvement in family obligations.

When analysing detailed work-life balance tools, one can note that a great majority of them also act as a motivational stimulus intended to influence employees (e.g., admission to cultural or sporting facilities, organizing events for special occasions, 
vouchers that help employees financially or health care packages). Whereas supporting employees in the reconciliation of professional and parental roles is far less frequent - here examples may include: contributing to the costs of holidays for children, flexibility of work time, remote work, contributing to childcare costs, inhouse nurseries, additional days off for families with children, longer maternal or parental leaves financed by employers. These tools also build an appropriate atmosphere at work, inspire creativity, attract valuable persons to work and build the company's reputation as an employer.

The WLB problem is an issue studied in many countries due to numerous consequences not only for the individual, but also companies and entire societies. Results of research carried out last year demonstrate that companies which offer WLB activities note cases of burnout and stress among their employees less often (Cascio, 2001, s. 192), which has a positive impact on work efficiency. Therefore, it can be concluded that creating an offer for the professional work-family life balance may contribute to building the company's competitive advantage. An employee's involvement in a professional career and family life at the same time leads to great tensions - especially in specific periods of life. Such a moment may include having to get more involved in family roles (looking after one's children, caring for dependent persons, caring for one's parents) in the course of a professional career at a time when an employee also steps into a particularly demanding stage due to an opportunity of promotion and taking up new responsibilities, which automatically entails increased involvement in the work role.

Research concerning WLB has also been carried out in Poland. A basic conclusion can be made on its basis that the issue of reconciling work and non-work life is not the strongest side of Polish companies.

A study carried out as part of the $6^{\text {th }}$ edition of the Human Resources Management Leader competition organised by IPISS in 2006 shows that only $36.4 \%$ of organizations treat WLB as an element of the company's official policy, and $50 \%$ of them treat it as the employee's individual issue (Urbaniak, Bohdziewicz, 2006, p. 134; Buchelt, Jupowicz, 2008, pp. 154-155). The research repeated in 2008 as part of the $9^{\text {th }}$ edition of the competition showed that $44 \%$ of organizations treat WLB as an element of the company's official policy while $56 \%$ as the employee's individual concern (Urbaniak, Bohdziewicz, 2008). Whereas research conducted in May 2006 by the Department of Labour and Social Policy of the University of Łódź concerning female employees shows much worse results. Only $14.5 \%$ respondents declared that they always or quite often saw manifestations of protection of the worklife balance from their companies, while close to 2/5 had never experienced this (Feliniak, Ratajczyk, 2008, p. 237). At the same time, this research showed that the larger the company, the less interested it was in problems of reconciling professional responsibilities with non-work life (Feliniak, Ratajczyk, 2008, p. 239).

Research carried out at the end of 2018 by Hays Poland shows that $38 \%$ of employees of large companies believe that the worklife balance is maintained at an average, bad or very bad level. At the same time, the said research shows that being able to maintain a healthy balance between work and private life is, from the point of view of the individual, one of the main reasons for considering changing jobs, and from the point of view of employers it is one of the elements which help the organization in attracting new talents (Hays, Mind\&Soul Center, p. 4). Research carried out at the same time by Mind \& Soul Center in cooperation with Mobile Institute demonstrates that $52 \%$ of respondents declare that their private life is subordinated to their work life, 50\% declare that they work over 40 hours a week, $46 \%$ of companies contact their employees outside office hours, while 34\% of respondents work after hours because the employer makes them (Hays, Mind\&Soul Center, p. 7).

The most recent research conducted by the Responsible Business Forum at the turn of

Patrycja ZWIECH (2021), Journal of Human Resources Management Research, DOI: $10.5171 / 2021.811071$ 
2019 and 2020 entitled "Professional work and fulfilment of care-related roles by women and men in Poland" showed that employers in a vast majority meet employees' expectations offering them various solutions that encourage reconciliation of work and care-related roles. As many as $80 \%$ of employees who are also carers declared this. Employers offer on average of 2-3 such opportunities (Baszun, Zamęcki, Joniewicz, 2020, p. 13). A detailed analysis showed that solutions most often offered by companies include being allowed to leave work upon request during the day for a short while with the possibility of covering this absence by using one's leave (36\% employers), flexible working hours (22\%), part-time employment (19\%), working from home (16\%), not reducing bonus due to taken leave, including sick leave (15\%), banning overtime for parents of children under 4 (15\%) and no shift work for persons with care-related responsibilities (13\%). Opportunities such as: in-house nurseries or a nurse hired by the company to visit adults in care of the company's employees were only applied by $3 \%$ of employers. Paying towards nurseries was applied by $6 \%$ of employers, payment towards carerelated services - 5\% (Baszun, Zamęcki, Joniewicz, 2020, p. 14).

\section{Methodology}

This study presents results of a survey of human resources management systems in companies of the West Pomeranian province carried out in the Institute of Human Capital Management of the University of Szczecin on a sample of 601 employees of the investigated companies (primary sources; for the adopted significance level (0.05) and admissible maximum error of estimation (+/- 4\%), it was established that 598 units were the minimum sample to ensure reliability of research).

The research was carried out in the period between March and May 2017, and the territorial scope covered the West Pomeranian province in Poland. Employees in the companies were the research population. An individual company employee was the sample unit where the questionnaire could reach many employees in individual companies. Data from sample units qualified to the sample were gathered by means of a questionnaire consisting of 78 questions, including 10 in the bio data segment. A random sample unit selection method was applied. In the analyses of differentiation of declarations in selected groups of respondents, four categories of differentiation were identified for the needs of this study: company size, gender, position in the company and length of service. This study uses respondents' answers to 2 questions from the questionnaire addressing the investigated matter. Out of the factors deemed most necessary for a successful life, 10 were selected for in-depth analysis: good health (X1), happy family (X2), good standard of living (X3), satisfying job (X4), respect among people (X5), a lot of free time (X6), education (X7), managerial position (X8), acting in accordance with religious teachings (X9) and political activity (X10).

\section{Results}

The investigated population were asked what in their opinion was most necessary for a successful life. A respondent could mark a maximum of 3 options. Table 1 presents the data in a general approach and in groups of respondents identified according to the company size criterion and the position held, length of service and gender. 
Table 1: Factors declared by respondents as most necessary for a successful life in general and in groups of entities distinguished due to size and in groups of respondents according to their position, length of service and gender (in \%)

\begin{tabular}{|c|c|c|c|c|c|c|c|c|c|c|}
\hline & $\begin{array}{c}\text { good } \\
\text { health }\end{array}$ & $\begin{array}{l}\text { happy } \\
\text { family }\end{array}$ & $\begin{array}{c}\text { good } \\
\text { standard } \\
\text { of living }\end{array}$ & $\begin{array}{c}\text { satisfying } \\
\text { job }\end{array}$ & $\begin{array}{l}\text { respect } \\
\text { among } \\
\text { people }\end{array}$ & \begin{tabular}{|c|} 
a lot \\
of \\
free \\
time \\
\end{tabular} & education & $\begin{array}{c}\text { managerial } \\
\text { position }\end{array}$ & \begin{tabular}{|c|} 
acting in \\
accordance \\
with \\
religious \\
teachings \\
\end{tabular} & $\begin{array}{l}\text { political } \\
\text { activity }\end{array}$ \\
\hline & $\mathrm{X} 1$ & $\mathrm{X} 2$ & X3 & $\mathrm{X} 4$ & $\mathrm{X} 5$ & $\mathrm{X} 6$ & $\mathrm{X7}$ & $\mathrm{X} 8$ & $\mathrm{X9}$ & $\mathrm{X} 10$ \\
\hline total & 26.6 & 24.8 & 20.7 & 13.5 & 5.3 & 3.6 & 3.5 & 0.9 & 0.7 & 0.4 \\
\hline micro & 27.4 & 26.1 & 19.1 & 13.7 & 5.2 & 3.6 & 3.6 & 0.6 & 0.6 & \\
\hline small & 26.1 & 23.3 & 22.2 & 14.7 & 4.5 & 3.5 & 2.7 & 1.8 & 0.6 & 0.6 \\
\hline medium-sized & 26.8 & 25.3 & 21.0 & 12.7 & 6.1 & 4.1 & 2.8 & & 0.8 & 0.5 \\
\hline large & 26.2 & 25.7 & 19.4 & 13.1 & 6.1 & 3.4 & 3.9 & 1.0 & 1.0 & 0.5 \\
\hline \multicolumn{11}{|c|}{ criterion: post held } \\
\hline higher-level manager & 25.3 & 30.7 & 16.0 & 12.0 & 12.0 & 2.7 & 1.3 & & & \\
\hline \multicolumn{11}{|c|}{ criterion: length of service } \\
\hline up to 0.5 year & 27.4 & 22.3 & 17.7 & 16.6 & 4.0 & 4.0 & 4.0 & 1.1 & 1.7 & 1.1 \\
\hline 0.5 to 1 year & 25.5 & 23.5 & 21.4 & 12.3 & 3.7 & 5.3 & 6.2 & 1.2 & 0.8 & \\
\hline 1 to 2 years & 27.3 & 24.8 & 21.1 & 11.2 & 6.2 & 4.1 & 3.3 & 0.8 & 0.8 & 0.4 \\
\hline 2 to 5 years & 26.3 & 26.0 & 22.1 & 14.1 & 5.4 & 3.6 & 1.7 & 0.5 & 0.2 & \\
\hline 5 to 10 years & 26.8 & 27.2 & 17.6 & 17.2 & 3.8 & 2.5 & 2.5 & 1.7 & & 0.8 \\
\hline more than 10 years & 26.7 & 25.5 & 20.7 & 11.4 & 8.1 & 2.4 & 3.3 & & 1.2 & 0.6 \\
\hline \multicolumn{11}{|c|}{ criterion: gender } \\
\hline
\end{tabular}

Source: author's own compilation on the basis of research results.

Good health (26.6\%), a happy family (24.8\%) and a good standard of living $(20.7 \%)$ were factors that respondents thought to be the most important for a successful life. If the responses pointing to good working conditions and a satisfying job were to be summed up, it would turn out that work is a factor that most determines a successful life. The other end of the summary (in a general approach) would include political activity $(0.4 \%)$, acting in accordance with religious teachings $(0.7 \%)$ and a managerial position $(0.9 \%)$.
The same order was preferred by respondents identified due to the company size criterion, where it needs to be noted that those from micro- and large enterprises valued a good standard of living slightly more than those working in small or medium-sized enterprises.

When analysing the responses in correlation to one's position, we can see that for people in highest positions the "respect among people" element is much more important than for other groups, while a "good standard of living" is

Patrycja ZWIECH (2021), Journal of Human Resources Management Research, 
statistically less important for them. Most probably this results from the fact that their needs of economic security (the sense of financial stability, securing income in the event of sickness or loss of income from the current job, having savings, insurance) are secured to a much greater degree than in other groups. According to A. Maslow's hierarchy of needs, human behaviour is motivated by two principles: deficiency and growth. The first one assumes that man strives to satisfy an unsatisfied need and for people in higher positions the need of security is usually satisfied. Thus, greater focus is given to the need for respect, desire to have good reputation and appreciation among other people.

Taking into account the length of service as the differentiating criterion, it needs to be concluded that employees with a shorter time of service overall more often point to the importance of the "a lot of free time" factor than other employee groups. Greater weight attributed to education is also noteworthy. In turn, employees with the length of service of over 10 years pointed to respect among people much more often than other groups.

The respondents' gender was the only factor that statistically differentiated their declarations. Good health, a happy family and a good standard of living were factors that both men and women thought to be the most important for a successful life. However, if we look at it closely, it turns out that declarations of both genders differed significantly. Both a happy family and a good standard of living were statistically more often declared by women than men. The difference for a good standard of living reaches 5.4 p.p., while for a happy family - 2.6 p.p. At the same time, men statistically more often than women pointed to "a lot of free time" and "education". Political activity, acting in accordance with religious teachings and a managerial position were at the opposite end of the summary, though the order was different for both genders. As the research has shown, women found the following to be the least important: acting in accordance with religious teachings $(0.3 \%)$, political activity $(0.5 \%)$ and a managerial position $(0.7 \%)$, while for men they were: political activity $(0.3 \%)$, a managerial position (1.5\%) and acting in accordance with religious teachings (2\%). The resulting differences concerned women's and men's attitudes to acting in accordance with religious teachings and the managerial position factor. What is interesting, men needed acting in accordance with religious teachings more than women to have a successful life.

In addition, the research focused on whether companies are trying to solve problems of reconciling work and private life by offering organizational solutions such as programmes facilitating the issue in question. Table 2 presents the structure of respondents' answers to the question whether their companies implement programmes facilitating reconciliation of work with private life. None of the criteria differentiating respondents' declarations proved statistically significant. 
Table 2: Structure of respondents' answers to the question whether their companies implement programmes facilitating reconciliation of work with private life in general and in groups of entities distinguished due to size and in groups of respondents according to their position, length of service and gender (in \%)

\begin{tabular}{|c|c|c|}
\hline $\begin{array}{l}\text { Implementation of programmes that } \\
\text { facilitate reconciling work with private } \\
\text { life }\end{array}$ & yes & no \\
\hline total & 51.3 & 48.7 \\
\hline \multicolumn{3}{|l|}{ criterion: entity size } \\
\hline micro & 54.1 & 45.9 \\
\hline small & 52.1 & 47.9 \\
\hline medium-sized & 49.2 & 50.8 \\
\hline large & 50.7 & 49.3 \\
\hline \multicolumn{3}{|l|}{ criterion: post held } \\
\hline regular worker & 51.3 & 48.7 \\
\hline lower-level manager & 56.1 & 43.9 \\
\hline mid-level manager & 46.8 & 53.2 \\
\hline higher-level manager & 52.2 & 47.8 \\
\hline \multicolumn{3}{|l|}{ criterion: length of service } \\
\hline up to 0.5 year & 48.3 & 51.7 \\
\hline 0.5 to 1 year & 55.7 & 44.3 \\
\hline 1 to 2 years & 53.8 & 46.2 \\
\hline 2 to 5 years & 50.4 & 49.6 \\
\hline 5 to 10 years & 51.9 & 48.1 \\
\hline more than 10 years & 49.5 & 50.5 \\
\hline \multicolumn{3}{|l|}{ criterion: gender } \\
\hline man & 48.5 & 51.5 \\
\hline woman & 52.2 & 47.8 \\
\hline
\end{tabular}

Source: author's own compilation on the basis of research results.

About half of respondents declared that their companies implement programmes that facilitate reconciliation of work with private life, with women pointing to it marginally more frequently than men $(52.2 \%$ and $48.5 \%$, respectively). Implementation of such programmes was also statistically more often pointed to by employees of micro-enterprises, lowerlevel managers and employees with a length of service between 0.5 to 1 year.

\section{Conclusion}

Contemporary economic and social changes result in increased problems and challenges associated with striving to shape appropriate relations between work and non-work life, including harmony between time and involvement devoted to the main spheres of functioning of professionally active people, that is work and family, giving the individual specific satisfaction from roles they play. The research conducted in Polish companies 
shows that activities undertaken by employers for mitigating the work-life conflict only do so for selected problems. Employees believed that good health, a happy family life, a good standard of living and a satisfying job are the most important factors to have a successful life and if one were to sum up responses which point to a good standard of living and a satisfying job, it would turn out that a job is a factor that most determines a successful life. At the same time, the research showed that only half of employees declared that their companies implement programmes facilitating reconciliation of work with private life.

Combining work with care-related responsibilities is a common thing among Polish employees, both male and female, therefore the employer's implementation of activities that support these persons in combining such roles is necessary. Meeting their expectations may prevent withdrawal from the labour market of people that are valuable to employers and may reduce employees' stress which inevitably translates into work efficiency.

\section{References}

- $\quad$ Baszun, R., Zamęcki, A., Joniewicz, T. (2020) Praca zawodowa a pełnienie ról opiekuńczych przez kobiety i mężczyzn w Polsce. Raport FOB i Karty Różnorodności, Forum Odpowiedzialnego Biznesu, Lipiec.

- Borkowska, S. (2003) o równowagę między praca $i$ życiem: Unia Europejska-Polska, Programy praca życie a efektywność firm, Borkowska S. (ed.), IPISS, Warszawa.

- Borkowska, S. (2004) Praca $i$ życie pozazawodowe, Przyszłość pracy $\mathrm{w}$ XXI wieku, Borkowska S. (ed.), IPISS, Warszawa.

- Borkowska, S. (2011) Ile pracy, ile życia poza niq̨?, Programy praca życie: z teorii i praktyki, Borkowska S. (ed.), IPISS, Warszawa.

- Buchelt, B., Jupowicz, E. (2008) Zmieniajacy się paradygmat rynku pracy a praktyka organizacji $w$ zakresie wspierania równowagi pracażycie zatrudnionych, Równowaga.
Praca-Życie-Rodzina, SadowskaSnarska C. (ed.), Wydawnictwo Wyższej Szkoły Ekonomicznej w Białymstoku, Białystok.

- Campbell Clark, S. (2000) 'Work/family border theory: a new theory of work/family balance', Human Relations 53(6), 747-770.

- Casio, W. (2001), Kalkulacja kosztów zasobów ludzkich, Dom Wydawniczy ABC, Kraków.

- Clutterbuck, D. (2005) Równowaga między życiem zawodowym a osobistym, Oficyna Ekonomiczna, Kraków.

- Feliniak, U., Ratajczyk, W. (2008) Problemy godzenia życia zawodowego i pozazawodowego kobiet regionu łódzkiego, Równowaga. Praca-ŻycieRodzina, Sadowska-Snarska C. (ed.), Wydawnictwo Wyższej Szkoły Ekonomicznej w Białymstoku, Białystok.

- Frone, M.R. (2003) Work-family balance, Handbook of Occupational Health Psychology, Quick, J.C., Tetrick, L.E. (eds), DC: APA, Washington, 143162.

- Greenhaus, J.H., Beutell, N.J. (1985) 'Sources of conflict between work and family roles', Academy of Management Review 10(1), 76-88.

- Greenhaus, J.H., Collins, K.M., Shaw, J.D. (2003) "The relation between work-family balance and quality of life', Journal of Vocational Behavior 63(3), 510-531.

- Greenhaus, J.H., Powell, G.N. (2006) 'When work and family are allies: a theory of work-family enrichment', Academy of Management Review 31(1), 72-92.

- Grzywacz, J.G., Marks, N.F. (2000) 'Reconceptualizing the work-family interface: an ecological perspective on the correlates of positive and negative spillover between work and family', Journal of Occupational Health Psychology 5(1), 111-126.

- Hays, Mind\&Soul Center (2019) Nowa Era Motywacji. Raport 2019.

- Kisil, A. (2018) Wyzwolenie pracy. Nowa ekonomia postkapitalistyczna, Capital, Warszawa. 
- $\quad$ Rapoport, R., Bailyn, L., Fletcher, J.K., et al. (2002) Beyond Work-Family Balance. Advancing Gender Equity and Workplace Performance, CA: Jossey Bass, San Francisco.

- Resch, M. (2003) Work-Life Balance: neue Wege der Vereinbarkeit von Berufs- und Privatleben? GfA Herbstkonferenz 29. und 30. September 2003. Aachen/Stuttgart: Ergonomia Verlag.

- Robak, E., Słocińska, A. (2014) Umiejętność równoważenia życia zawodowego z osobistym w aspekcie wartościowania pracy, Relacje praca życie zawodowe. Droga do zrównoważonego rozwoju jednostki, Tomaszewska-Lipiec Renata (ed.), Wydawnictwo Uniwersytetu Kazimierza Wielkiego, Bydgoszcz, pp. 113-130.

- Sadowska-Snarska, C. (2014) Koncepcja równowagi praca-życie $w$ kontekście zmian zachodząych $w$ sferze ekonomicznej i społecznej, Relacje praca - życie pozazawodowe drogą do zrównoważonego rozwoju jednostki, Tomaszewska-Lipiec, B. (ed.), Wydawnictwo Uniwersytetu Kazimierza Wielkiego w Bydgoszczy, Bydgoszcz.

- Urbaniak, B., Bohdziewicz, P. (2006) Zarządzanie zasobami ludzkimi kreowanie nowoczesności, Raport z badań VII edycji konkursu Lider Zarządzania Zasobami Ludzkimi, IPISS, Warszawa.

- Urbaniak, B., Bohdziewicz, P. (2008) Zarządzanie zasobami ludzkimi kreowanie nowoczesności, Raport $\mathrm{z}$ badań IX edycji konkursu Lider Zarządzania Zasobami Ludzkimi, IPISS, Warszawa.

- Warhurst, C., Eikhof, D.R., Haunschild, A. (2008) Work Less, Live More? Critical Analysis of the Work-Life Boundary, Palgrave Macmillan, Houndsmills and New York. 